\title{
INTERGRATING MULTIMODALITY AND JIGSAW READING IN TEACHING READING COMPREHENSION TO YOUNG LEARNERS \\ (A Case Study at Fifth Grade of Islamic Elementary School of Al Azhar 18 Cianjur)

\author{
Nia Kurniawati ${ }^{1}$ Ai Komariah ${ }^{2}$ Elis Homsini Maolida $^{3}$ Vina Aini Salsabila ${ }^{4}$ \\ nia@unsur.ac.id ${ }^{1}$ \\ elishomsini@unsur.ac.id ${ }^{3}$ \\ vinaainisalsabila@gmail.com ${ }^{4}$
}

Suryakancana University

Aikomariah_01@yahoo.co.id ${ }^{2}$

SDIT Al AZHAR Cianjur

English young learners' ability in reading comprehension is considerably below teachers' expectation. Many students still rely on direct translation technique in comprehending reading text. Various techniques were developed to improve young learners reading comprehension such as jigsaw reading. However, teaching young learners need to involve all the senses as multimodality offers. The aims of the current study were (1) to gain some description on the process of integrating multimodality and jigsaw reading technique in teaching reading comprehension to young learners; (2) to examine the students' response on the utilizing multimodality and jigsaw reading technique at a private elementary school; and (3) to find out the difficulties faced by the teacher in applying the technique. This research involved a class of five grader of $\mathrm{Al}$ Azhar 18 Islamic elementary school in Cianjur. It applied qualitative approach. The instruments used were observation sheet, interview, and document analysis. The results showed that there are three steps in applying the chosen technique including preparation, practice, and evaluation. The students' response positively to the technique, since it gives them chance to work in a group and ask things they don't know to their peer, and are very excited with different media provided by the teachers. As for the teachers, the difficulties are more related to the time constraints in preparing the materials that should be very vary and handling the grouping with diverse level of English among the young learners. 
Keywords: multimodalities, reading comprehension, action research, English for young learners

\section{INTRODUCTION}

In Indonesia, interest in teaching English to young learners has been steadily growing in recent years. Many parents believe that by studying English from early stage, their children will get a better future. They believe that by introducing English to their children as early as possible, it will bring their children to have a better carrier. In Cianjur, West Java, some elementary schools put English in their curriculum although in early childhood education new curriculum, for example the 2013 curriculum, do not included English as their attention, but every elementary school has its own authority to expand their curriculum.

English has been urged to be one of the local-content subjects beginning to be taught in the fourth grade of elementary school or Sekolah Dasar (SD), and in the last last five years, there have been many schools which have started to introducing English even earlier, beginning from the first grade of the elementary school. The survey conducted by Yusfardiah (2010), which examined 42 out of 348 SDs in a city in Sumatera chosen randomly, showed that $100 \%$ had included include English in as their local content curriculum subject.

However, PISA (2007) found out that the reading proficiency level of Indonesian students was still low: $28.8 \%$ at below level 1, 36.5\% at level 1, 29.1\% at level $2,11.1 \%$ at level 3, $1.5 \%$ at level 4 , and $0.1 \%$ at level 5 (OECD/PISA, 2007; see also Topping et al., 2003). This condition did not improve in 2009. According to PISA 2009 database, Indonesian students' mean score was below the OECD average and puts Indonesia in 57th place out of 65 countries. The score on the students' ability on the overall reading scale was 402 while the OECD average score was 493 . Furthermore, on the reading subscales, the achievement of Indonesian students are as follows: the score of their ability to access and retrieve was 399 , to integrate and interpret was 397 , to reflect and evaluate was 409, to comprehend continuous texts was 405 and to comprehend non-continuous texts was 399 (OECD, 2010). UNDP (2009) also reported that Indonesian adult literacy rate was 92, 88th place among 180 countries (cited in Diem, 2011). 
The teaching of reading skills to young learners is often overlooked in schools. There are some issues and concerns in the field of teaching English in elementary school in Indonesia. Students are rarely encouraged to read, and seldom have opportunities to read. Many young learners can't really know how successful reader they are because of the lack of practice, lack of attention from the teacher, and the use of inappropriate strategies in the teaching of reading.

Based on these considerations, this study was conducted to answer the following questions;

1.How is the process of integrating multimodality and jigsaw reading technique in teaching reading comprehension to young learners;

2.How do the students respond to multimodality and jigsaw reading technique integration in teaching young learners reading comprehension?

3.What are the difficulties faced by the teachers in applying multimodality and jigsaw reading technique integration in teaching young learners reading comprehension?

\section{THEORETICAL FRAMEWORKS}

There are some theories underpinning the research. Most of them are related to teaching reading, reading comprehension, teaching young learners in EFL setting, and multimodalities.

\section{Teaching Reading}

Reading is an essential skill for learners for life-not just for learning with reading being defined as "...the ability to draw meaning from the printed page and interpret this information appropriately" (Grabe \& Stoller, 2002, p. 9 cited in Arnold and Malcolm, 2016). An aspect that should be considered to interpret the information is having reading comprehension which is defined as the most of what a student might know about a text, after reading (Ekwall and Shanker, 1993). There are three models that describe the process of comprehending a text, and they are the bottom-up, topdown, and interactive models. From these three models, researchers such as Wallace (1992), Vacca \& Vacca (2005), Ogle (1986), and others have argued about which reading model best explains the process of reading comprehension and which can develop successful readers (cited in Hosani, 2011).

\section{Jigsaw Reading Technique}


Traditional reading class is carried out by the teacher's reading the text being discussed then by some students' reading in turns. The teacher poses a question; the students wanting to respond raise their hands; the teacher calls on one particular student and the chosen student tries to state the correct answer. This particular classroom structure can be changed to make the class more interactive by jigsaw technique.

In jigsaw technique students form groups of 4-5 students. They initially gather in their 'home group'. Each student is assigned to read a different part of a reading text. Students with the same part then make a group called an 'expert group' to discuss and master their own part. Then they go back to their own 'home group' to exchange the information. All members of the home group should at last understand the whole text. Every member should be responsible for his or her own part and responsible for the success of all teammates in comprehending the text.

\section{Multimodality}

Multimodality (Kress, Jewitt, Ogborn, \&Tsatsarelis, 2001; Kress \& van Leeuwen,1996), like multiliteracies, has emerged in response to the changing social and semiotic landscape. Key to multimodal perspectives on literacy is the basic assumption that meanings are made (as well as distributed, interpreted, and remade) through many representational and communicational resources, of which language is but one (Kress \& van Leeuwen, 1996). This and other aspects of multimodal theory are outlined by Kress and van Leeuwen's (1996) Multimodal Discourse.

Multimodality attends to meaning as it is made through the situated configurations across image, gesture, gaze, body posture, sound, writing, music, speech, and so on. From a multimodal perspective, image, action, and so forth are referred to as modes, as organized sets of semiotic resources for meaning making. To some extent, multimodality can be described as an eclectic approach, although it is primarily informed by linguistic theories, in particular, the work of Halliday's (1978) social semiotic theory of communication and developments of that theory (Hodge \&Kress, 1988). In similar vein, Mills (2011) sees multimodal as the term for 
portraying the intricacy and interconnectedness of modes for making meaning: linguistic, visual, auditory, gestural, or spatial modes.

\section{Teaching Young Learners}

Every learners has the different characteristic as the individual, one and others. Saurock and Yussen (1972) said that each us develops some other individuals, and like individuals, like some other individuals, and like no other individuals (cited in Sajidiman, 2012, p.22).

Young learner is categorized as students from ages three to eight years old (Wilson, 2003, n.p.). There is also age limitation for young learners which comes from Pinter (2006) who limits the age groups of young learners from five to fourteen years old (cited in Brown, 2001, n.p.)Related to the definition of young learners before, young learners can be defined as the students who are classified by the age group under fourteen years old.

In teaching, there are many factors that should be considered by the teachers. One of them is the learner age. Dealing with adult learner will be very much different from young learners. In teaching young learners, there is so much to consider as it has been mentioned by Read (2003) as (a) learning is natural, (b) learning is contextualized and part of a real event, (c) learning is interesting and enjoyable, (d) learning is relevant, (e) learning has a purpose for the child, (f) learning makes sense to the child, and (g) learning is active and experimental

\section{METHOD}

Regarding the burning issue about the integration of multimodalities and jigsaw reading technique in teaching reading comprehension to young learners that needs an in depth qualitative investigation, this research utilizes case study design. It is chosen because it has the potential to provide an in-depth understanding of process rather than outcome (Hood, 2009, p.2). This approach also has potential to provide an in-depth understanding of process rather than outcome (Hood, 2009, p.2).

The research was conducted at a private elementary school in Cianjur. This school is one of the schools that require teach English as local subject in its policy. 
This research site was also chosen because it willingly accepted the researchers to conduct the study.

The participants of this study were a class teacher and her class and 28 students from lower level of grade 5 who were willingly join the study. For ethical issues consideration in qualitative research the informed consent forms are given to the participants.

The data are gained from several sources including classroom observation, indepth interview with participants, and document analysis. Those methods are applied in order to ensure the internal validity for triangulation purposes.

The classroom observation was conducted to give chances to the researcher to draw inference on the respondent point of view, the event or the observable process. Through observation, the tacit (implicit) knowledge and theory-in-us of the respondents can be seen.

Note was taken on everything that was going on in the observed teacher's classroom including her teaching method, English skills and also the students respond to her teaching in the classroom.

The interview was also carried out to obtain other supporting data for this study. The qualitative research interview has been described as a 'conversation with a purpose' (Burgess, 1984, p.102 cited in Richards, 2009, p. 181). The interview tried to dig deeper on learners' attitude toward the use of English in teaching mathematics and their own native language use. The interview was conducted after the class observation and questionnaire submission. The interview is guided or semi-structured enabling the researcher to get all information required while at the same time permitted the participants to probe some aspects in depth (Richards, 2009, p. 186).

To get the picture of the learners' reading comprehension competence and the process of the teaching in the classroom, the researcher used the secondary data e.g. the learners' weekly scores, English text book and also the students' worksheet. As it is explicated earlier, the research is not to get quantitative data in numbers but to reveal more in-depth understanding about the process and the impact of the use of multimodalities and jigsaw reading in teaching reading comprehension to young learners. Therefore, since this research is qualitative in nature, then the data analyses were conducted during and after the research (Alwasilah, 2009). During research data analyses were including classroom observation; and interview were transcribed and analyzed. 
A data source triangulation, which is the most desired pattern for dealing with the case study data (Yin, 2003) were conducted to make contrast and comparison of all data obtained from different sources, i.e. questionnaire, classroom observation, interview and document analysis. This is to enhance the validity of the conclusion of the study.

Observation gave real picture of the practice of teaching reading by utilizing the technique in the classroom; it revealed the problems faced by both teacher and students. The interview gave chance to the teacher to clarify everything happened in the classroom and also her opinion about the techniques she has to apply.

\section{FINDINGS AND DISCUSSION}

The focus of this research covers three issues, the implementation, the students' response, and the obstacles that the teacher encountered in applying multimodalities and jigsaw reading technique in teaching reading comprehension to young learners.

\section{The process of integrating multimodality and jigsaw reading technique in teaching reading comprehension to young learners}

In answering the first research question, the observation was conducted for four times. While observing, the researcher tried to record all the steps carried out by the teachers in implementing the technique. Basically, there are three steps carried out by the teacher. It includes preparation, practices, and evaluation.

In preparing the teaching, the teacher introduced main vocabularies that the students would find in the text. In introducing the vocabularies, presentation in the form of pictures in digital book was displayed. Then picture drilling was conducted by looking at the pictures in the slides. It was then continued by involving the students in kinesthetic games by matching vocabularies and their definition. 


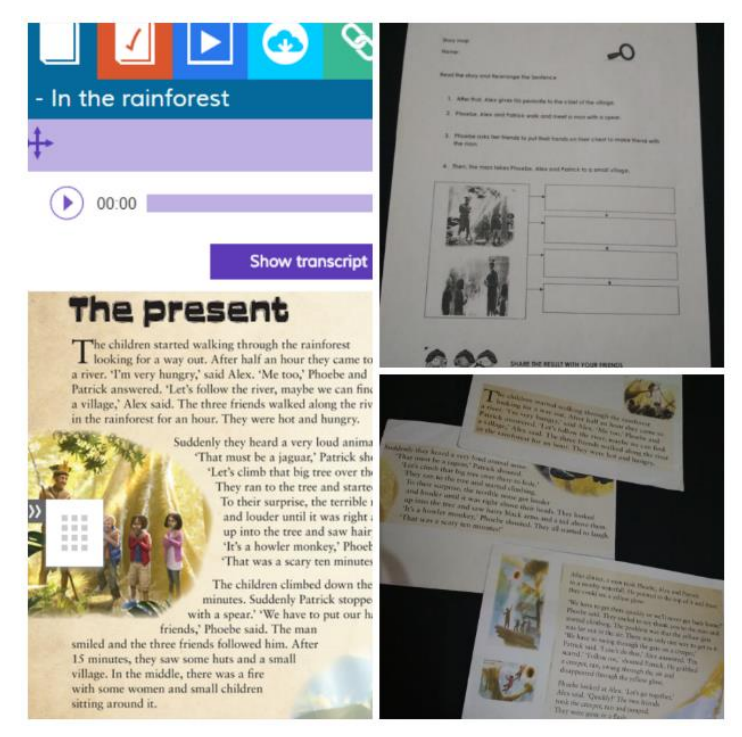

Picture 1. The use of multimodality in teaching reading

In practicing reading activity, the teacher showed the pictures that related to text (story) based on the chronological order of the story. While showing the pictures, the teacher was playing the audio of the text. By showing the pictures and playing the audio at the same time, the students got multimodal sources to activate their comprehension toward the text. Then, the teacher asked the students to read the text silently while listening the audio. A session of discussing difficult and new vocabularies was conducted so the students had background knowledge to read and comprehend the text.

After that, the students were divided into several groups to form expert groups who should focus to read two paragraphs from the text. In the expert groups, the students read the text, discussed the content and filled the graphic organizer to map the story. In this case, the students proceeded their reading process by utilizing multimodals of the text and graphic organizer. The teacher made sure all students worked and their answers were correct beacuse they would share the result to other students. Then the students formed home group where the students shared the result of their work in expert group. In the home group, the students shared, discussed and order the story in the graphic organizer with the whole members of group to form the whole story.

To evaluate students' comprehension of the text, worksheets were distributed to the students. Through the worksheets, the students matched the statements and the 
reasons, chose correct answers and wrote the correct sentences corresponding with the displayed pictures.

\section{The students' responses on the utilizing multimodality and jigsaw reading technique at a private elementary school}

Based on the result of observation and interview, most of students responded positively toward the integration of multimodal and jigsaw reading. It can be seen from their attitude and involvement in the learning process. In the beginning, the students focused on the displayed pictures and the played audio. Even though they were young learners who often considered as having short attention span, in this activity they showed a high curiousity. No body chatted with other classmates, all of them looked to the screen and listened to the audio.

In addition, the students also showed active involvement in the activity. They moved quickly to follow teacher's instruction, distributed themelves into groups, read the text together and discussed the text. In discussing the text, most of the students were active giving their opinion to order parts of the story.

Furthermore, their positive responses were shown by the students' eagerness of asking about the vocabularies and content of the text. The questions appeared after reading the text session and in the expert group session. In the expert group session, all groups also competed to finish reading the text and fill the graphic organizer.The result of worksheet also supports the fact of students' positive responses. Most of students obtained good score that shows their succesfull comprehension toward the text by integrating multimodal and jigsaw reading.

However, the result of observation and interview also reveal that few students did not prefer group works in the jigsaw reading. It was because, they said, group works took time and were more complicated comparing to individual work. They also mentioned that it was noisy in the group work session. It seems that less positive response related to students' learning types and preference.

When the students were asked whether they enjoyed the activity ,all students said 'yes' and they wanted to apply this activity for other texts. Few students suggested, however, to combine group and individual works in the process. 


\section{The difficulties faced by the teacher in applying the technique}

There were at least three obstacles faced by the teacher in integrating multimodal and jigsaw technique. The first obstacle related to the content of the texts. In the interview, the teacher mentioned that the level of text was quite difficult for fifth grader with high range of vocabularies and specific topics such as disaster and rainforest. In addition, the grammatical complexity of the text was considered as quite difficult by the teacher.

The second obstacle concerned with involving all the students in the jigsaw activity. Most of the students actually worked actively. However, few students looked hesitant and passive and they only followed and looked at other students' work. In this case, the teacher tried to come closer to those students and pushed them to involve in the discussion.

The third obstacle related with classroom management. Since jigsaw activitty involved group works, it sometimes took time to divide the class into groups and regroup the students. Furthermore, the fact that few students preferred solo work added the obstacles. Those students who preferred solo work tend to work individually even though they were in the middle of group.

\section{CONCLUSION}

There are several conclusions drawn from the current study. In the implementation of multimodalities and jigsaw reading technique for teaching reading comprehension, the teacher should spare more time in preparing the materials. In the classroom, teacher should also be able to handle the class in grouping the students, considering the difference level of skill among the students as well as managing the time limit for each activity. The students found the technique beneficial since it helps them to understand the text. Even sometimes they still asked the teacher to translate some difficult words within the text. However, the students found some obstacles in the practice, they mentioned that the text is too difficult for them since the texts used were taken from the resource book provided by the school and it is different and different from other public school. Besides, some of less active students could not really involve in the group work. While the stronger students were preferred to work alone, since they thought that the rest of the group work too slow, and gave no effort in 
accomplishing the assignment. But overall, the students enjoy the class while using this technique and consider it fun and helpful in comprehending reading texts. It is because multimodalities could stimulate all of the students' senses such as their visual and audiolingual sense. Therefore, the information from the reading text will retain longer, and at the end it helps to improve their reading comprehension.

There are some suggestions for those who want to apply the same technique in teaching young learner reading. Teacher should be more careful in selecting the text, it should be not too far from the students' level of comprehension. The teacher should not translate too much and let the students practice their reading skill independently. Hopefully, by implementing the text, the students' level of comprehension would be improving.

\section{References}

Alwasilah, A. C. (2009). Pokoknya Kualitatif. Jakarta: Pustaka Jaya.

Arnold, W., Malcolm, F. (2016). Reading and young learners. British Council. Retrieved from https://www.teachingenglish.org.uk/article/reading-young-learners.

Brown, H.D. 2001. Teaching by Principles. An Interactive Approach to Language Pedagogy. Englewood Cliffs: Prentice Hall.

Diem, C.D. (2011). A Model for Teaching Young Learners. TEFLIN Journal. 22(2).

Ekwall, E., \& Shanker, J. (1993). Locating and correcting reading difficulties. New York: Macmillan.

Halliday, M. (1978). Language as a social semiotic. London: Edward Arnold.

Hodge, R., \& Kress, G. (1988). Social semiotics. Cambridge, UK: Polity.

Hood,M. 2009. Case Study. In Heigham.J., and Croker, R.A. (2009) Qualitative Research in Applied Linguistics, United Kingdom, Palgrave Mc Millan.

Hosani, H.H.A. (2011). The Development of Young Learners' Reading Comprehension Skills. Retrieved from http://marifa.hct.ac.ae/files/2011/06/The-Development-ofYoung-Learners-Reading-Comprehension-Skills.pdf

Kress, G., Jewitt, C., Ogborn, J., \& Tsatsarelis, C. (2001). Multimodal teaching and learning: The rhetorics of the science classroom. London: Continuum.

Kress, G., \& van Leeuwen, T. (1996). Reading images: The grammar of visual design. London: Routledge.

Read. Carol. 2003. Teaching Young Learners: Introduction; Available at http://www.teachingenglish.org.uk/transform/teachers/specialist-areas/teaching-younglearners [Accessed at November 9, 2011] 
Richards, K. 2009. Interview. In Heigham.J., and Crokr, R.A. (2009) Qualitative Research in Applied Linguistics, United Kingdom, Palgrave Mc Millan.

Sajidiman, D. (2012). Perkembangan Peserta Didik. (not published)

Wilson, L. (2003). Importance of Early Children hood Education in Your Child's Life. Retrieved April 17, 2016 from: http://tiger.towson.edu/ 1wilson1/reserach/paper.htm

Yin, R.K. 2003. Case Study Research, Design and Methods. Third Edition, London: Sage Production.

Yusfardiah. (2010). The Correlations Between the Teachers' Performance and their Pupils' Achievement in English for Young Learners Based on Grade and Gender. Unpublished Thesis. Palembang: Graduate School of Sriwijaya University.Sriwijaya University. 